\title{
An Ethnobotanical Study of Medicinal Plants in the Greek Islands of North Aegean Region
}

\author{
Evangelos Axiotis, Maria Halabalaki* and Leandros A. Skaltsounis
}

Department of Pharmacognosy and Natural Products Chemistry, Faculty of Pharmacy, National and Kapodistrian University of Athens, Athens, Greece

Greek islands of the North Aegean Region are a group of nine inhabited islands (Lemnos, Agios Efstratios, Lesvos, Chios, Psara, Oinousses, Samos, Ikaria, and Fourni) located in the northern part of the Aegean Sea, close to Asia Minor. Each island of this region can be considered autonomous in terms of culture and biodiversity. With this work we try to evaluate the status of the traditional uses of medicinal plants in this region. Endemic and endangered species such as Sideritis sipylea Boiss., Origanum sipyleum L., Thymus sipyleus Boiss., Pistacia lentiscus L., Verbascum ikaricum Murb., are still used by locals to treat different ailments. Moreover, the use of some species for the treatment of specific diseases has been reported for the first time. We report about 109

OPEN ACCESS

Edited by:

Atanas G. Atanasov,

Institute of Genetics and Animal

Breeding (PAS), Poland

Reviewed by:

Sevser Sahpaz,

Lille University, France

Ligia Salgueiro,

University of Coimbra, Portugal

${ }^{*}$ Correspondence:

Maria Halabalak

mariaha/@pharm.uoa.gr

Specialty section:

This article was submitted to

Ethnopharmacology,

a section of the journal

Frontiers in Pharmacology

Received: 08 December 2017

Accepted: 09 April 2018

Published: 23 May 2018

Citation:

Axiotis E, Halabalaki $M$ and

Skaltsounis LA (2018) An

Ethnobotanical Study of Medicinal

Plants in the Greek Islands of North

Aegean Region.

Front. Pharmacol. 9:409.

doi: 10.3389/fphar.2018.00409 wild plants of medicinal importance, from 52 families, listing their uses for therapeutic purposes and galenic preparations provided by local medical doctors and pharmacists. The information we include was derived from literature sources and additionally collected through semi-structured interviews conducted on 200 informants (100 men and 100 women). Additionally, informant consensus factor (FIC) and UV value were calculated for the medicinal plants in the current study in relation with the diseases treated. This research confirms the importance of the medicinal plants and the diffusion of their use in traditional medicine within this region. This ethnopharmacological survey is a fundamental step for the preservation of the local knowledge both for further scientific research and for the protection of endangered and endemic medicinal plants.

Keywords: ethnopharmacology, traditional medicine, Near East Greek islands, North Aegean Sea, ethnobotany

\section{INTRODUCTION}

Greece holds a unique position with respect to the number of plant species and subspecies compared to other areas of the globe. This depends on the variety of habitats, as well as on geological history, climate conditions, and geographical position within the Mediterranean. Thus, it is noted for its high plant species diversity (5800 species and 1893 subspecies) and endemism (22.2\% of all species present with 1278 species and 452 subspecies) (Davis, 1965-1986; Tutin et al., 1968-1980; Strid, 1986; Strid and Tan, 1991, 1997, 2002; Georgiou and Delipetrou, 2010).

The Northeast Aegean islands offer a unique ecosystem with significant "hotspots" for various plant diversification responses and endemism. This depends on the fact that Aegean Sea is an archipelago of continental islands placed on the conjunction of Europe, Asia, and Africa (Gogou et al., 2016). The available "ecological space" with "environmental heterogeneity" in addition with the "land-bridge system" with the continents determined a high floristic diversity 
and endemism (Kallimanis et al., 2011). Several botanical studies have been conducted on these islands (Christodoulakis, 1986, 1996; Panitsa et al., 1994, 2006; Panitsa and Tzanoudakis, 1998, 2001; Snogerup et al., 2001; Bazos, 2005). However, there is limited information regarding the medicinal plants and traditional plant remedies in this area.

Nowadays the use of plants and traditional medicine plays an important role for the discovery of new pharmacological agents. Ethnopharmacology represents a multidimensional approach, shaped by tradition and science that can improve our knowledge of plant use and local meaning of health and disease (World Health Organization [WHO], 2002). The aim of this study is threefold: to present a complete list of the medicinal plants used in traditional medicine in the islands of Northeast Aegean Sea, preserve information about their use and, lastly, highlight the use in traditional medicine of endemic and endangered plant species, in order to prevent their extinction.

\section{MATERIALS AND METHODS}

\section{Study Area}

The current study was conducted on the islands and islets of the northeast edge of the Aegean Sea and is dominated by the islands of Lemnos, Agios Efstratios, Lesvos, Chios, Psara, Oinousses, Samos, Ikaria, and Fournoi (Figure 1). The geographical coordinates of the islands are represented in Supplementary Table 4 . The region covers an area of $3835 \mathrm{~km}^{2}$ and has approximately 2500 vascular plant species.

The terrain of the islands is $33 \%$ mountainous, 35\% hilly, and $32 \%$ flat. The surface area and the maximum elevation ranged from $40 \mathrm{~km}^{2}$ for Psara and Fourni to $1633 \mathrm{~km}^{2}$ for Lesvos and from 0 to $1433 \mathrm{~m}$ of height (Kerketea mt, Samos), respectively (Higgins and Higgins, 1996). The islands can be grouped in two phytogeographical zones among the 13 existing in Greece (Supplementary Figure 1); the zone of the Northern Aegean (NAe) with Lemnos and Agios Efstratios and the zone of the Eastern Aegean (EAe) with Lesvos, Psara, Chios, Oinousses, Samos, Ikaria and Fournoi, with specific climatic differences (Rauh, 1949). The palaeography and the geological events that separated these islands from Anatolian mainland, certain environmental parameters (temperature and humidity) and habitat diversity in well-defined fragmented areas, are among the causes of the high endemism, floral richness and diversification in quantity and quality of many secondary metabolites that characterize the pharmacological properties of many species of the study area (Panitsa et al., 2010).

\section{Methodology}

The information summarized in the present paper was compiled from 15 randomly selected villages from the islands of the surveyed area (Figure 1). The methodology followed in the field surveys is based on Fujita et al. (1995). The data was collected through semi-structured interviews performed with local people (Martin, 1995). After explaining the purpose of our research, a questionnaire in Greek was administered to the informants including questions about their age, education, and interest in traditional medicine. A total of 200 people was surveyed, 100 women and 100 men, with an average age of 40. The informants with knowledge about medicinal plants were questioned multiple times, and, during the interviews, local names of the plants, utilized parts, preparation methods and traditional cultivation techniques were recorded. The majority of these skillful informants were medical doctors, pharmacists, and farmers. All the results are summarized in Supplementary Table 1 . The data acquired for each plant includes family, botanical name, local name in Greek, locality, voucher number, parts used and their preparation, therapeutic effect and ailments treated. The plant families were listed in alphabetical order.

Field trips were conducted with the interviewees to collect specimens of the plants (with the exception of the endangered ones). A photographic archive of the observed species was created to help the identification. The specimens were collected and herborized by the department's herbarium with a specific voucher number. Furthermore, we examined the therapeutic effect and preparations of each plant based on the informants' feedback and on literature records.

For the analysis of the use of the medicinal plants against specific diseases, we used informant consensus factor (FIC), summarized in Supplementary Table 3 (Trotter and Logan, 1986; Heinrich, 2000). Moreover, the Use Value (UV) was calculated to demonstrate the relative importance of the species known locally, summarized in Supplementary Table 1. The plant species scientific names were verified according to the Plant List and to the International Plant Name Index. Information that was not possible to confirm was not recorded. Moreover, in Supplementary Table 1, we reported some of the most important bibliographic references for plant species and ailments treated that were not mentioned by the informants (Snogerup and Snogerup, 1987, 1993; Panitsa et al., 1994, 2006, 2010; Snogerup et al., 2001; Bergmeier et al., 2003; Bazos, 2005; BourbonnaisSpear et al., 2006; Saliaris, 2008; Axiotis and Axiotis, 2012; Strid, 2016).

\section{RESULTS AND DISCUSSION}

In the context of the current survey numerous medicinal plants were ethnopharmacologicaly investigated (in Supplementary Table 1). The interviews indicated that 109 wild plant species from 52 different families are being used for medicinal purposes. Lamiaceae family is represented by the highest number of species (17), such as the endemic and endangered Sideritis sipylea Boiss. Asteraceae family is represented by 12 species. Brassicaceae and Rosaceae by 5 species. The rest of the plant families are shown in Supplementary Figure 2. Most of the plant parts were used to treat different diseases and they were mostly stored in glass bottles as homemade dry powders obtained by crushing down well-dried plant materials; the most frequently used parts are leaves $(22,8 \%)$, roots $(12,78 \%)$, flowers $(11,41 \%)$, essential oils $(7,30 \%)$, fruits $(6,84 \%)$, and barks $(5 \%)$. The most common preparation is the decoction. 


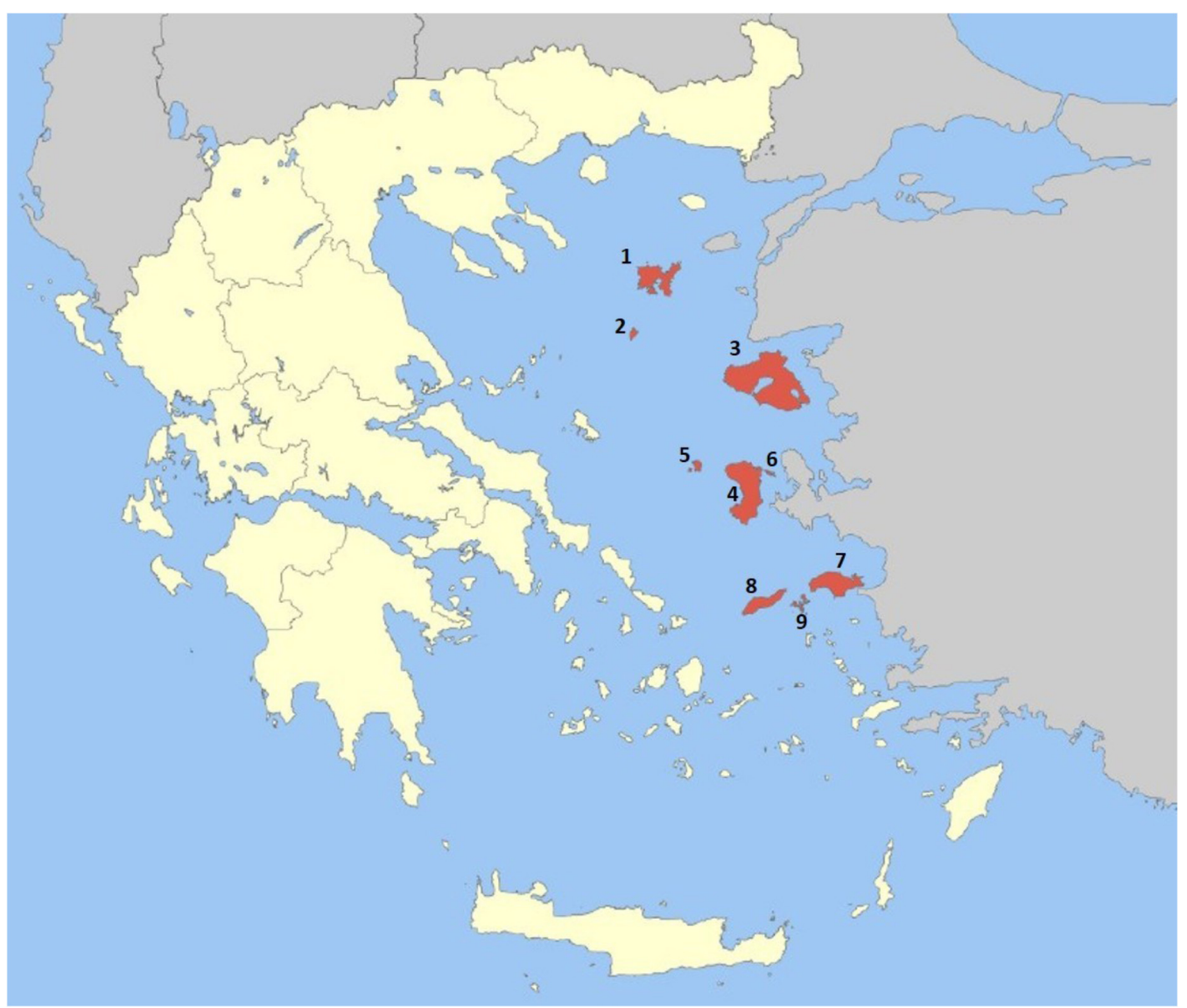

FIGURE 1 | Geographical location of the study area (Islands in red). Collection sites of the information are as follows. (1) Lemnos, (2) Agios Efstratios, (3) Lesvos, (4) Chios, (5) Psara, (6) Oinousses, (7) Samos, (8) Ikaria, (9) Fourni (http://www.pvaigaiou.gov.gr).

Interestingly, Hypericum perforatum L. and Verbascum ikaricum Murb. are kept in olive oil and used as solutions for wounds and sun burns. Pharmacists from Lesvos, Chios and Samos, still use these preparations as traditional therapy for skin wound healing in combination with modern treatments. Furthermore, clinicians from Lesvos use the powder of the root of Alkanna tinctoria for skin regeneration after injuries. They observed a combined antibacterial and antipruritic action, which reduces the healing time of the wound. It is important to note that Sideritis sipylea Boiss., Origanum sipyleum L., Thymus sipyleus Boiss., which are endemic and endangered plants are mostly used by the local people of Lesvos, Chios, and Ikaria with many curative purposes, especially for the infections of the respiratory and gastrointestinal tract as indicated from the UV values (Supplementary Table 1).

Furthermore, the resin of Pistacia lentiscus L., unique product globally of the Chios island is widely used against diarrhea, as expectorant and for ulcer healing. The use of the water extract of the roots of Anthyllis hermanniae L. as an efficient natural remedy against kidney stones in Lesvos and Lemnos, is reported here for the first time. It was also observed that local people, especially farmers, use the same name for different plant species. For example, Cistus creticus L. and Cistus salvifolius L. are both called "Aksistaros"; Origanum vulgare L. and the endemic and endangered Origanum sipyleum L. are both called "Rigani." This lack of distinction by the local population exacerbates the risks for the endangered species.

Very interesting is the distribution of ailments treated versus plant species used. As it is presented in Figure 2, locals are choosing herbal remedies mainly for antimicrobial activity, gastrointestinal disorders, respiratory, inflammatory, cardiovascular diseases, and skin burns. In Supplementary Table 3, FIC values of categories of ailments are summarized. Hormonal diseases have the highest FIC value $(0,722)$, while the lowest belongs to the cardiovascular diseases $(0,161)$. Moreover, among the species recorded (Supplementary Table 1), the highest UV were calculated for Matricaria chamomilla L. (0.75) and Lavandula stoechas L. (0.64). From the endemic species the highest UV is recorded for Sideritis sipylea Boiss. (0.31).

Essential oils are also common in the region, mainly derived from aromatic plants of Lamiaceae family and they are produced by water or steam distillation. The oils are usually used as drops directly on the skin or in galenic formulations, for skin infections or burns. In some cases, they are used for stomach pain (Anthemis sp.) or even for urinary infections (Sideritis sipylea Boiss.). The most common plants used for producing essential oils are Salvia 


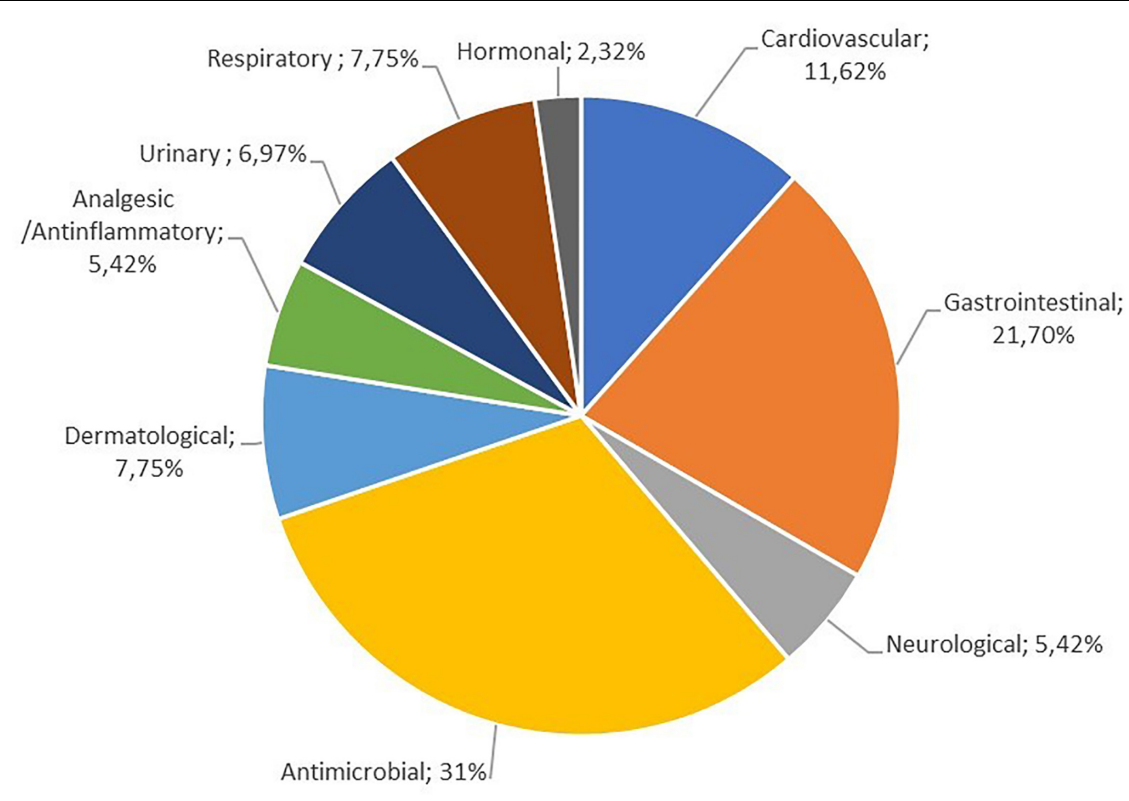

FIGURE 2 | Distribution of ailments treated versus plant species used.

fruticosa Miller, Salvia officinalis L., Origanum vulgare L., Sideritis sipylea Boiss., and Lavandula stoechas L. Furthermore, it has been reported a traditional method for the production of rose oil of the flower petals of Rosa damascena Mill. in a small village of Lesvos. The oil is used for external burns or skin inflammations.

The pharmacological properties of medicinal plants presented in the current study has been also verified by published data, in several cases. For example, the essential oil of Laurus nobilis L., used as anti-inflammatory is reported by Sayyah et al. (2003). The expectorant effect of Cistus creticus L. and the use of Mentha spicata L. in cases of common cold have been reported by Fakir et al. (2009). Tonic effects of Rosmarinus officinalis L. and the diuretic effects of Raphanus raphanistrum L. have been reported by Bruni et al. (1997). The essential oil of Sideritis species presents an important antimicrobial and anti-inflammatory activity and it has been previously reported by Aligiannis et al. (2001).

Generally, these plants are distributed mainly in Lesvos, Chios, Samos, and Ikaria and the majority are wild. A serious threat for some of these plants, is that they are collected in large amounts for the local markets; some of them, such as Sideritis sipylea Boiss., Origanum sipyleum L., Thymus sipyleus Boiss., are in fact listed in the book of the Red List of Threatened Species. Many species, such as Origanum vulgare L. and Paeonia mascula (L.) Mill. subsp. mascula are not yet listed but their population is in a critical condition. Endemic medicinal plants of the research area are also annotated in Supplementary Table 2.

A very important issue is the increased use of medicinal plants in these islands which has led to heavy pressure on the native populations of many species. The local population must acknowledge their endangerment and should cultivate them, in order to protect their populations from extinction. Sideritis sipylea Boiss. is one of the over harvested species. Habitat loss and deforestation in Lesvos, Chios, and Samos resulted in a general degradation of the ecosystems that could lead to the extinction of many species.

In conclusion, from this brief report is clear that medicinal plants are an important element of indigenous medical system of Northeast Aegean islands. In spite of the fact that the local population has access to modern medicines, many people continue to depend, at least for the treatment of some diseases, on herbal remedies. These therapies represent for many local doctors a low-cost alternative. The population of many endemic species such as Sideritis sipylea Boiss., Origanum sipyleum L., are in a critical condition due to unsustainable harvesting techniques, habitat destruction, and absence of cultivation. The endemic species of the area have medicinal properties dependent on the metabolites which respond to environmental stimuli that may be absent under culture conditions. Because of this it is very important to educate local people about respecting their natural habitats and strengthen the legislation against the illegal trade of endemic and endangered plants in the local and national market.

\section{AUTHOR CONTRIBUTIONS}

EA contributed to the study conception and design of the methodology. Moreover, he was responsible for the analysis and the interpretation of data. $\mathrm{MH}$ contributed substantially to supervising the work and drafting the manuscript. LS contributed to the critical and final revision of the manuscript.

\section{FUNDING}

This research received specific grant from North Aegean Region, Greece NSRF 2014-2020 (National Strategic Reference Framework). 


\section{ACKNOWLEDGMENTS}

The authors thank all the local people who shared their knowledge of plants and Dr. Makis Axiotis for the valuable information provided to the present study.

\section{REFERENCES}

Akin, M., Aktumsek, A., and Nostro, A. (2010). Antibacterial activity and composition of the essential oils of Eucalyptus camaldulensis Dehn. and Myrtus communis L., growing in Northern Cyprus. Afr. J. Biotechnol. 9, 531-535. doi: 10.5897/AJB09.1562

Aligiannis, N., Kalpoutzakis, E., Chinou, I. B., Mitakou, S., Gikas, E., and Tsabropoulos, A. (2001). Composition and antimicrobial activity of the essential oil of five taxa of Sideritis from Greece. J. Agric. Food Chem. 49, 811-815. doi: 10.1021/jf001018w

Aubert, P., Guinobert, I., Guilbot, A., and Neunlist, M. (2016). Antispasmodic and spasmolytic activity of Melissa officinalis EPS upon mice gastrointestinal tract: an ex vivo pilot study. Planta Med. 82, S1-S381. doi: 10.1055/s-00361596945

Axiotis, M., and Axiotis, E. (2012). Medicinal Plants of Greece. The Research in Lesvos Island. Athens: Endelexeia Editions.

Bahmani, M., Shirzad, H., Rafieian, S., and Rafieian-Kopaei, M. (2015). Silybum marianum: beyond hepatoprotection. J. Evid. Complementary Altern. Med. 20, 292-301. doi: 10.1177/2156587215571116

Bazos, I. (2005). Study of the Flora and Vegetation of Lesvos. Ph.D. thesis, University of Athens, Athens.

Bergmeier, E., Dimopoulos, F., and Dimopoulos, P. (2003). The vegetation of islets in the Aegean and the relation between the occurrence of islet specialists, island size and grazing. Phytoenologia 33, 447-474. doi: 10.1127/0340-269X/2003/ 0033-0447

Bourbonnais-Spear, N., Poissant, J., Cal, V., and Arnason, J. (2006). Culturally important plants from southern Belize: domestication by Q'eqchi' Maya healers and conservation. Ambio 35, 138-140. doi: 10.1579/0044-7447(2006)35[138: CIPFSB]2.0.CO;2

Bruni, A., Ballero, M., and Polli, F. (1997). Quantitative ethnopharmacological study of the Campidano Valley and Urzulei district, Sardinia, Italy. J. Ethnopharmacol. 57, 97-124. doi: 10.1016/S0378-8741(97)00 055-X

Cayci, M. K., and Dayioglu, H. (2009). Hypericum perforatum extracts healed gastric lesions induced by hypothermic restraint stress in Wistar rats. Saudi Med. J. 30, 750-754.

Christodoulakis, D. (1986). Flora and Vegetation of Samos. Ph.D. thesis, University of Patras, Patras.

Christodoulakis, D. (1996). The flora of Ikaria (Greece, E. Aegean Islands). Phyton $36,63-91$.

Dadalioglu, I., and Evrendilek, G. A. (2004). Chemical compositions and antibacterial effects of essential oils of Turkish oregano (Origanum minutiflorum), bay laurel (Laurus nobilis), Spanish lavender (Lavandula stoechas L.), and fennel (Foeniculum vulgare) on common foodborne pathogens. J. Agric. Food Chem. 52, 8255-8260. doi: 10.1021/jf049033e

Davis, P. H. (1965-1986). Flora of Turkey and the East Aegean Islands, Vol. 10. Edinburgh: Edinburgh University Press.

Fakir, H., Korkmaz, M., and Güller, B. (2009). Medicinal plant diversity of Western Mediterranean region in Turkey. J. Appl. Biol. Sci. 3, 30-40.

Friedman, M. (2014). Chemistry and multibeneficial bioactivities of carvacrol (4isopropyl-2-methylphenol), a component of essential oils produced by aromatic plants and spices. J. Agric. Food Chem. 62, 7652-7670. doi: 10.1021/jf50 23862

Fujita, T., Sezik, E., Tabata, M., Yesilada, E., Honda, G., Takeda, Y., et al. (1995). Traditional medicine in Turkey vii. Folk medicine in middle and west Black Sea regions. Econ. Bot. 49, 406-422. doi: 10.1007/BF02863092

Gambarana, C., Tolu, P. L., Masi, F., Rinaldi, M., Giachetti, D., Morazzoni, P., et al. (2001). A study of antidepressant activity of Hypericum perforatum on animal models. Pharmacopsychiatry 34, S42-S44. doi: 10.1055/s-200115515

\section{SUPPLEMENTARY MATERIAL}

The Supplementary Material for this article can be found online at: https://www.frontiersin.org/articles/10.3389/fphar. 2018.00409/full\#supplementary-material

Gasparetto, J. C., Martins, C. A., Hayashi, S. S., Otuky, M. F., and Pontarolo, R. (2011). Ethnobotanical and scientific aspects of Malva sylvestris L.: a millennial herbal medicine. J. Pharm. Pharmacol. 64, 172-189. doi: 10.111/j.2042-7158. 2011.01383.x

Georgiou, K., and Delipetrou, P. (2010). Patterns and traits of the endemic plants of Greece. Bot. J. Linn. Soc. 162, 130-422. doi: 10.111/j.1095-8339.2010.01025.x

Gogou, A., Triantaphyllou, M., Xoplaki, E., Izdebski, A., Parinos, C., Dimiza, M., et al. (2016). Climate variability and socio-environmental changes in the northern Aegean (NE Mediterranean) during the last 1500 years. Quat. Sci. Rev. 136, 209-228. doi: 10.1016/j.quascirev.2016. 01.009

Heinrich, M. (2000). Ethnobotany and its role in drug development. Phytother. Res. 14, 479-488. doi: 10.1002/1099-1573(200011)14:7<479::AID-PTR958>3. $0 . \mathrm{CO} ; 2-2$

Hentschel, C., Dressler, S., and Hahn, E. G. (1995). Fumaria officinalis (fumitory) Clinical applications. Fortschr. Med. 113, 291-292.

Higgins, M. D., and Higgins, R. (1996). A Geological Companion to Greece and the Aegean. Ithaca, NY: Cornell University Press.

Kallimanis, A. S., Panitsa, M., Bergmeier, E., and Dimopoulos, P. (2011). Examining the relationship between total species richness and single island palaeo- and neo-endemics. Acta Ecol. Int. J. Ecol. 37, 65-70. doi: 10.1016/j.actao.2010. 11.008

Khan, S., and Sharma, N. R. (2016). Antifungal potential of ethanol extracts of Allium sativum and Allium ampeloprasum. Asian J. Pharm. Clin. Res. 10, 1-4.

Koksal, E., Bursal, E., Dikici, E., Tozoglu, F., and Gulcin, I. (2011). Antioxidant activity of Melissa officinalis leaves. J. Med. Plants Res. 5, 217-222.

Lattanzio, F., Greco, E., Carretta, D., Cervellati, R., Govoni, P., and Speroni, E. (2011). In vivo anti-inflammatory effect of Rosa canina L. extract. J. Ethnopharmacol. 137, 880-885. doi: 10.1016/j.jep.2011.07.006

Lone, B. A., Chishti, M. Z., Bhat, F. A., Tak, H., Bandh, S. A., and Khan, A. (2017). Evaluation of anthelmintic, antimicrobial and antioxidant activity of Chenopodium album. Trop. Anim. Health Prod. 49, 1597-1605. doi: 10.1007/ s11250-017-1364-y

Longaray Delamare, A. P., Moschen-Pistorello, I. T., Artico, L., Atti-Serafini, L., and Echeverrigaray, S. (2007). Antibacterial activity of the essential oils of Salvia Officinalis L. and Salvia triloba L., cultivated in South Brazil. Food Chem. 100, 603-608. doi: 10.1016/j.foodchem.2005.09.078

Martin, G. J. (1995). Ethnobotany: A Methods Manual. London: Chapman and Hall.

Meral, G. E., Konyalioglu, S., and Ozturk, B. (2002). Essential oil composition and antioxidant activity of endemic Ziziphora taurica subsp. cleonioides. Fitoterapia 716-718. doi: 10.1016/S0367-326X(02)00244-7

Mirzaei, A., Delaviz, H., Mirzaei, M., and Tolooei, M. (2015). The effects of Medicago sativa and Allium porrum on iron overload in rats. Glob. J. Health Sci. 7, 137-142. doi: 10.5539/gjhs.v7n7p137

Panitsa, M., Dimopoulos, P., Iatrou, G., and Tzanoudakis, D. (1994). Contribution to the study of the Greek flora: flora and vegetation of the Enousses (Oinousses) islands (E. Aegean area). Flora 189, 69-78. doi: 10.1016/S0367-2530(17) 30570-4

Panitsa, M., Trigas, P., Iatrou, G., and Sfenthourakis, S. (2010). Factors affecting plant species richness and endemism on land-bridge islands - An example from the East Aegean archipelago. Acta Oecologica 36, 431-437. doi: 10.1016/j.actao. 2010.04.004

Panitsa, M., and Tzanoudakis, D. (1998). Contribution to the study of the Greek flora: flora and vegetation of the E. Aegean islands Agathonisi and Pharmakonisi. Willdenowia 28, 95-116. doi: 10.3372/wi.28.2809

Panitsa, M., and Tzanoudakis, D. (2001). A floristic investigation of the islet groups Arki and Lipsi (East Aegean area, Greece). Folia Geobot. 36, 265-279. doi 10.1007/BF02803180

Panitsa, M., Tzanoudakis, D., Triantis, K. A., and Sfenthourakis, S. (2006). Patterns of species richness on very small islands: the plants of the 
Aegean archipelago. J. Biogeogr. 33, 1223-1234. doi: 10.1111/j.1365-2699.2006. 01481.x

Rauh, W. (1949). Klimatologie und Vegetations verhältnisse der Athos-Halbinsel und der ostägeischen Inseln Lemnos, Hag. Evstratios, Mytilene und Chios. Heidelberg: Heidelberger, 511-615.

Saliaris, P. (2008). Natura Chia. A Journey to the Flora and Fauna of Chios island. Chios: Egeas Editions.

Sayyah, M., Saroukhani, G., Peirovi, A., and Kamalinejad, M. (2003). Analgesic and antinflammatory activity of the leaf essential oil of Laurus nobilis Linn. Phytother. Res. 17, 733-736. doi: 10.1002/ptr.1197

Shara, M., and Stohs, S. J. (2015). Efficacy and safety of white willow bark (Salix alba) extracts. Phytother. Res. 29, 1112-1116. doi: 10.1002/ptr.5377

Singh, J., Dubeyd, A. K., and Tripathi, N. N. (1994). Antifungal activity of Mentha spicata. Pharm. Biol. 32, 314-319. doi: 10.3109/13880209409083009

Snogerup, S., and Snogerup, B. (1987). Repeated floristical observations on islets in the Aegean. Plant Syst. Evol. 155, 143-164. doi: 10.1007/BF00936296

Snogerup, S., and Snogerup, B. (1993). Additions to the flora of Samos, Greece. Flora Medit. 3, 211-222.

Snogerup, S., Snogerup, B., Phitos, D., and Kamari, G. (2001). The flora of Chios island (Greece). Bot. Chron. 14, 5-197.

Soni, P., Siddiqui, A. A., and Soni, V. (2012). Pharmacological properties of Datura stramonium L. as a potential medicinal tree: an overview. Asian Pac. J. Trop. Biomed. 2, 1002-1008. doi: 10.1016/S2221-1691(13)60014-3

Strid, A. (1986). Mountain Flora of Greece, Vol. 1. Cambridge: Cambridge University Press.

Strid, A. (2016). Atlas of the Aegean Flora. Part 1: Text \& plates. Part 2: Maps. Berlin: Botanic Garden and Botanical Museum Berlin.

Strid, A., and Tan, K. (1991). Mountain Flora of Greece, Vol. 2. Edinburgh: Edinburgh University Press.

Strid, A., and Tan, K. (1997). Flora Hellenica 1. Königstein: Koeltz Scientific Books. Strid, A., and Tan, K. (2002). Flora Hellenica 2. Ruggell: Koeltz Scientific Books.

Süntar, I., Koca, U., Keleş, H., and Akkol, E. K. (2011). Wound healing activity of Rubus sanctus Schreber (Rosaceae): preclinical study in animal models," Evid. Based Complement. Alternat. Med. 2011:816156. doi: 10.1093/ecam/nep137

Tapondjou, A. L., Adler, C., Fontem, D. A., Bouda, H., and Reichmuth, C. (2005). Bioactivities of cymol and essential oils of Cupressus sempervirens and Eucalyptus saligna against Sitophilus zeamais Motschulsky and Tribolium confusum du Val. J. Stored Prod. Res. 41, 91-102. doi: 10.1016/j.jspr.2004. 01.004

Tomczyk, M., and Latté, K. P. (2009). Potentilla - A review of its phytochemical and pharmacological profile. J. Ethnopharmacol. 122, 184-204. doi: 10.1016/j. jep.2008.12.022
Trotter, R. T., and Logan, M. H. (1986). "Informant consensus: a new approach for identifying potentially effective medicinal plants," in Plants in Indigenous Medicine and Diet, Behavioural Approaches, ed. N. L. Etkin (New York, NY: Redgrave Publishing Company).

Tunalier, Z., Kosar, M., Ozturk, N., and Baser, H. C. (2004). Antioxidant properties and phenolic composition of Sideritis species. Chem. Nat. Compd. 40, 206-210. doi: 10.1023/B:CONC.0000039124.83109.ac

Tutin, T. G., Heywood, V. H., Burges, N. A., Moore, D. M., Valentine, D. H., Walters, S. M., et al. (1968-1980). Flora Europaea, Vol. 2. Cambridge: Cambridge University Press.

Wang, Y., Xiang, L., Wang, C., Tang, C., and He, X. (2013). Antidiabetic and antioxidant effects and phytochemicals of mulberry fruit (Morus alba L.) polyphenol enhanced extract. PLoS One 8:e71144. doi: 10.1371/journal.pone. 0071144

Wittschier, N., Faller, G., and Hensel, A. (2009). Aqueous extracts and polysaccharides from liquorice roots (Glycyrrhiza glabra L.) inhibit adhesion of Helicobacter pylori to human gastric mucosa. J. Ethnopharmacol. 125, 218-223. doi: 10.1016/j.jep.2009.07.009

Woelk, H., Burkard, G., and Grinwald, J. (1994). Benefits and risks of the hypericum extract LI 160: drug monitoring study with 3250 patients. J. Geriatr. Psychiatry Neurol. 4(Suppl.1), S34-S38. doi: 10.1177/089198879400700110

World Health Organization [WHO] (2002). WHO Traditional Medicinal Strategy 2002-2005. Geneva: World Health Organization.

Yayalacı, Y., Celik, I., and Bat , B. (2014). Hepatoprotective and Antioxidant activity of linden (Tilia platyphyllos L.) infusion against ethanol-induced oxidative stress in rats. J. Membr. Biol. 247, 181-188. doi: 10.1007/s00232-0139622-Z

Yildirim, A., Mavi, A., and Kara, A. A. (2001). Determination of antioxidant and antimicrobial activities of Rumex crispus L. extracts. J. Agric. Food Chem. 49, 4083-4089. doi: 10.1021/jf0103572

Conflict of Interest Statement: The authors declare that the research was conducted in the absence of any commercial or financial relationships that could be construed as a potential conflict of interest.

Copyright (c) 2018 Axiotis, Halabalaki and Skaltsounis. This is an open-access article distributed under the terms of the Creative Commons Attribution License (CC BY). The use, distribution or reproduction in other forums is permitted, provided the original author(s) and the copyright owner are credited and that the original publication in this journal is cited, in accordance with accepted academic practice. No use, distribution or reproduction is permitted which does not comply with these terms. 